\title{
The Application of Eportfolio in Higher Education: implications for Student Learning
}

\section{Andrea Ximena Castaño Sánchez ${ }^{\mathrm{a}}$}

Data de defensa: $27 / 06 / 2014$

\begin{abstract}
Paraules clau: PLE, eportfolio, learning environment, higher education, self-regulated learning.
\end{abstract}

\begin{abstract}
Nowadays universities are introducing educational changes in their teaching practices and their assessment strategies. These changes are involving many areas in the university. One of the places where most of the changes are initiated is from the classroom settings. To support them, eportfolios in general are being used as a form to align the principles stated from the Bolonia Process towards a teaching more centred on the student supporting other aspects like mobility and recognition. Therefore, developing effective use of technology applied to education for teaching and learning has become an important challenge. In this regard, the main goal of this thesis was to identify learning environment characteristics when applying eportfolios for teaching and learning and students' characteristics that could influence a meaningful learning.

First of all, the primary aspects to know were the implications and scope that the eportfolio as a digital tool and pedagogically has had in education around the world and to the local level, where this research has been applied. This also included identifying areas where the application of eportfolio touch most of the educational settings. So the theoretical outline started from the more general where eportfolio learning can be seen as an educational innovation due to its support to the continual transformation of the higher education. Consequently, it has been influenced by aspects of the teaching and learning that range from diverse methodologies, changes towards teaching centred on the student and the changes of roles of educators
\end{abstract}

\footnotetext{
${ }^{a}$ Ph.D in Technology Applied to Education and Knowledge Management. Departament de Pedagogia. Universitat Rovira i Virgili - Tarragona
} 
towards guidance and most importantly lifelong learning. Also, due to the nature of electronic portfolio as a tool that is supported by educational technology. The literature review shows the technologies and computer applications developed specifically to attend the purpose of electronic portfolio; some of them are categorized as open, open source, independent platforms, or owned by an institution or Learning Management System.

Also, in this study the application of eportfolio follows the vision of being operated towards an open movement. Moreover, the three eportfolio experiences carried out during this research made use of the open source Mahara system integrated with the Learning Management System Moodle. Although, there is a movement towards the complete application of eportfolios using distributed resources from the cloud that are part of the Social Web. The Mahara eportfolio platform provides a bridge between the open use of digital resources and the institutionalized administration of the students' eportfolios through the learning management system. This study shows that the utilization of a system like Mahara can be the medium that place the blurred boundaries of usability for Web 2.0 tools, eportfolios and the LMS. This association describes the relation among the formal, non-formal and informal education. Attweell (2007) has seen this relation before by the advent of use of Web 2.0 tools that canimprove formal learning through personal learning environments and personal learning networks.

Also, this study validate the vision of Barrett \& Garrett (2009), H. Barrett (2005) and Chuang (2010) where eportfolio software is in the center of the developments in Web 2.0 services, Knowledge Management Systems within institutions, personal learning environments (PLE) and Learning Management Systems (LMS).

On the other hand, in order to know the state of research related with learning eportfolios in higher education, a literature review was conducted on published studies about different perspectives of eportfolios application. Some of the main categories about the effects of eportfolio application in students learning are based on the development of cognitives habilities, self-regulated learning, students characteristics, students' approaches to learning, perceptions about evaluation and attitudes towards the tool, teaching practice, professional development, perceptions of students and teachers and analysis of eportfolio systems. Also, the application of eportfolio for teaching and learning has been studied from different theoretical approaches and methodological perspectives.

This research takes as a base the methodologies oriented to its application for learning and reflection towards the use of digital resources. In this sense, we grouped the methodologies proposed by the process of eportfolio development from the three levels of construction proposed by Barret (2009).

A framework for eportfolio implementation proposed by Light, Chen \& Ittelson (2010) where they highlight the steps towards eportfolio implementation in classroom guided by a series of prompting questions that becomes an iterative process and the need that the stakeholders agree in how student learning is 
documented. A model for reflection for eportfolios proposed by Ruth Johnson et al. (2006) that classifies reflection in eportfolio in four different types: goal statements, reflective statements, captions as statements and assessment and evaluation statements, so artifacts are linked to specific purposes and goals within the eportfolio through reflections.

Also, a model of self-regulated learning for eportfolios that has been applied by (Abrami et al., 2008) based on (Zimmerman, 2000, 2001) model of self-regulation of learning that provides a framework for the development of a tool to support the three cyclical phases of self-regulated learning: forethought, performance and reflection. Another source for eportfolio implementation is taken from the proposed principles for practitioners to develop an effective practice by the organization (Joyes, Gray, \& Hartnell-Young, 2010; JISC, 2010, 2012).

Finally, the design and integration of eportfolios when applied for learning and/or assessment need clear guidelines of eportfoliocourse integration in order to promote deep learning centred environments. Organizing core activities that can promote reflection, and the relational nature of knowledge and identity development. Also, planning integration of eportfolio to enhance course design by using Fink (2009) model of integrative course design with eportfolios which is based in the decisions that teachers need to make in order to organize a systematic experience with learning eportolios, based in five key aspects situational factors, learning goals, feedback and assessment, teaching and learning activities and integration.

This research has focused on studying the application of eportfolio learning combined with teaching methodologies and aligned with assessment to allow students to easily integrate digital resources in order to create knowledge and enhance learning.

The specific objectives were:

a)To identify the usability of the electronic portfolio as a digital learning environment towards reflection about practice and the use of the social web.

b) To identify factors related with eportfolio application and students characteristics that can support or hinder students' learning

c) To analyze students' approaches to learning and students regulation of learning in digital learning environments supported with eportfolios.

In order to reach these objectives, three studies were conducted in the application of eportfolios for learning and assessment analyzed from different characteristics of classroom settings and learners' characteristics.

The first study was conducted as a learning strategy with electronic portfolios. It was designed and implemented in order to be used in a Master level of Teacher Training Erasmus Mundus during the course of "educational innovation" and in a bachelor 
course of "Developing of Technological Resources". The research design carried out consisted on qualitative analysis. This study adopted two different methods of data gathering: a documentary analysis of the content which students created through the eportfolio by reflecting on assignments, analyzing activities and self-assessment of eportfolio process and, a focus group interviews with a sample of the participating students. The eportfolio was intended to analyze their level of reflection and students attitudes and use of the artifacts and digital resources.

The second study was conducted in the context of higher education at the Rovira i Virgili University with two groups of students attending the grades of Pedagogy and Nursing. The aim of this study was to analyze the relationship of students' approaches towards learning and their assessment preferences for traditional assessment and eportfolio assessment. The characteristics of the two courses differed regarding the initial training in the eportfolio Mahara provided to students, the pedagogy course was in their last year of study and the Nursing course was in the second year of studies and the students have previously receivedtechnical and methodological training with the eportfolio.

The analysis consisted in the research questions related with a) How the encouraging/discouraging factors of the time demand and student effort, feedback and assessment preference (eportfolio/traditional) relate with students' approaches to learning? b) How the dominant approach to learning influence the activities with eportfolios and the traditional assessment for the integrated sample? c) How eportfolio assessment has influenced the approaches to learning in the disciplines of Teacher Education and Nursing?

Overall, the results showed a significant positive association among feedback and deep study approach, preference for both types of assessment non-traditional and traditional assessment. Relations of deep approach to learning and the time students spend on their eportfolios. The way the feedback is administered to students with the tool influences their perceptions of eportfolios. Also, a good quality of feedback can overcome the quantity of feedback. However, this study didn't show a relation on students' deep study approaches and eportfolio work. Instead, it has shown an opposite relation between surface learning and eportfolio work.

The third study was conducted with bachelor students of child education fourth year, during the course 'Teaching and learning experimental sciences, social sciences and Mathematics III' this study shows the rigorous design of eportfolio strategy to support teaching and learning. It was organized through a careful design of learning activities and initial training on eportfolio tool and methodology. The course was designed by the teacher having in mind the use of eportfolio to be worked in groups in order to cope with a large course of 138 students.

The methodology used consisted in mixed methods quantitative and qualitative data using three validated questionnaires that were validated by the researcher with the study, and content analysis using grounded theory and open coding based on the literature. 
The results of this study showed a significant increase in deep approach to learning after the assignments performed and documented with the eportfolio. Also, it showed a good level of reflection about their teaching practice and the usability with the eportfolio towards a positive use of the tool and the time they have to do the assignment. Also, the quantitative results showed a good level of awareness with their self-regulated skills while working with the assignment and the eportfolio tool. There was an evidence of students' identification with their teaching practice. 